\title{
Uitval zonder diploma: Aanleiding, Kansen en Toekomstintenties
}

Citation for published version (APA):

Meng, C. (2018). Uitval zonder diploma: Aanleiding, Kansen en Toekomstintenties. ROA. ROA Fact Sheets No. 018 https://doi.org/10.26481/umarof.2018018

Document status and date:

Published: 01/01/2018

DOI:

10.26481/umarof.2018018

Document Version:

Publisher's PDF, also known as Version of record

\section{Please check the document version of this publication:}

- A submitted manuscript is the version of the article upon submission and before peer-review. There can be important differences between the submitted version and the official published version of record.

People interested in the research are advised to contact the author for the final version of the publication, or visit the DOI to the publisher's website.

- The final author version and the galley proof are versions of the publication after peer review.

- The final published version features the final layout of the paper including the volume, issue and page numbers.

Link to publication

\footnotetext{
General rights rights.

- You may freely distribute the URL identifying the publication in the public portal. please follow below link for the End User Agreement:

www.umlib.nl/taverne-license

Take down policy

If you believe that this document breaches copyright please contact us at:

repository@maastrichtuniversity.nl

providing details and we will investigate your claim.
}

Copyright and moral rights for the publications made accessible in the public portal are retained by the authors and/or other copyright owners and it is a condition of accessing publications that users recognise and abide by the legal requirements associated with these

- Users may download and print one copy of any publication from the public portal for the purpose of private study or research.

- You may not further distribute the material or use it for any profit-making activity or commercial gain

If the publication is distributed under the terms of Article $25 \mathrm{fa}$ of the Dutch Copyright Act, indicated by the "Taverne" license above, 


\section{Maastricht University ROA}

Uitval zonder diploma:

Aanleiding, Kansen en Toekomstintenties

\section{ROA Fact Sheet}

ROA-F-2018/18

Researchcentrum voor Onderwijs en Arbeidsmarkt | ROA

Research Centre For Education and the Labour Market / ROA 


\section{Uitval zonder diploma: Aanleiding, Kansen en Toekomstintenties}

\section{Inleiding ${ }^{1}$}

Waarom verlaten jongeren ongediplomeerd het onderwijs? Wat waren de vroege signalen van de voortijdige uitval? Wat doet deze groep jongeren anderhalf jaar na het ongediplomeerd verlaten van het onderwijs en hebben ze spijt van het afbreken van de opleiding? Deze en andere vragen staan centraal in deze factsheet.

De groep jongeren die in deze factsheet centraal staan zijn jongeren die het onderwijs zonder diploma van de laatst gevolgde opleiding verlaten, jonger dan 23 jaar oud zijn en niet in het bezit zijn van een startkwalificatie. Zij maken daarmee deel uit van de groep voortijdig schoolverlaters. ${ }^{2}$

De in deze factsheet gepresenteerde cijfers zijn afkomstig van enquêtes die in het najaar van 2017 door het CBS afgenomen zijn als onderdeel van het project SchoolverlatersInformatieSysteem (SIS) van het Researchcentrum voor Onderwijs en Arbeidsmarkt (ROA) aan de Universiteit te Maastricht (UM). De vragenlijst is ingevuld door 1422 jongeren over het schooljaar 2015/2016. Landelijk verlaat ongeveer $1,72 \%$ van de jongeren per jaar de opleiding voortijdig, dit zijn om en nabij 23.000 leerlingen. Door het relatief laag aantal jongeren dat aan deze enquête heeft deelgenomen is het belangrijk de gepresenteerde cijfers met enige voorzichtigheid te interpreten.

\section{Achtergrondkenmerken van de respondenten} Wie zijn de jongeren die aan het onderzoek deelgenomen hebben? In deze paragraaf wordt aan de hand van enkele achtergrondkenmerken een beeld geschetst om welke jongeren het gaat. Een uitgebreide tabel met de verdeling over enkele achtergrondkenmerken is te vinden in Bijlage Tabel B1.

1 Deze factsheet is tot stand gekomen als onderdeel van het Project Onderwijs-Arbeidsmarkt (POA; http://roa.sbe.maastrichtuniversity.nl/?portfolio=poa-project-onderwijs-arbeidsmarkt-2), mede dankzij financiering van NRO (dossiernummer 405-17-900), UWV, S-BB en Randstad.

2 Voortijdige schoolverlaters worden gedefinieerd als jongeren die op het moment dat ze het onderwijs verlaten jonger dan 23 jaar oud zijn en geen diploma, op minimaal mbo niveau 2 dan wel de havo of het vwo, bezitten. Jongeren die het onderwijs na het behalen van een vmbo-diploma of een mbo niveau 1 diploma verlaten worden n.a.v. deze definitie als voortijdige schoolverlaters beschouwd. Echter, in deze factsheet worden zij buiten beschouwing gelaten.
Opleidingskenmerken

De overgrote meerderheid van de respondenten komt van het mbo (78\%). Respondenten afkomstig van de havo en vmbo opleidingen maken er allebei ongeveer 9\%-punt uit en. De resterende $3 \%$-punt is afkomstig van het vwo.

De sector Economie (34\%) vormt de grootste opleidingssector onder de respondenten, gevolgd door de sector Techniek (22\%) en de sector Gezondheidszorg (15\%).

\section{Leeftijd en geslacht}

De jongeren zijn anderhalf jaar na het verlaten van de opleiding gemiddeld 20 jaar oud, variërend van zo'n 18 jaar voor vmbo-uitvallers tot 20 jaar voor mbo-uitvallers.

Er zijn duidelijk meer mannen die voortijdig stoppen met hun opleiding dan vrouwen. Het percentage mannen onder de respondenten is $63 \%$. Dit verschilt echter wel tussen de verschillende opleidingsniveaus: $58 \%$ van de mbo niveau 1 respondenten is man tegenover $69 \%$ bij de respondenten van het vmbo. respondenten van mbo niveau 1 is man terwijl dit percentage bij de vmbo-respondenten $69 \%$ is.

\section{Etniciteit}

Over het algemeen is $62 \%$ van de respondenten autochtoon. Dit percentage verschilt echter over de onderwijsniveaus waarbij op het mbo niveau 3 het aandeel het grootst is $(73 \%)$ en op het vmbo het laagst (42\%). Verder heeft gemiddeld $29 \%$ een niet-westerse migratieachtergrond, waarbij onder de respondenten van het vmbo dit percentage het hoogst is, namelijk $47 \%$.

\section{Thuissituatie}

Van alle jongeren die aan de enquête hebben deelgenomen komt $60 \%$ uit een tweeoudergezin, $23 \%$ komt uit een eenoudergezin en $14 \%$ woont zelfstandig. De cijfers verschillen licht tussen de onderwijsniveaus waarbij opvalt dat 'slechts' $42 \%$ van de respondenten afkomstig van het mbo niveau 1 uit een tweeoudergezin komt.

Thuis wordt door $66 \%$ van de respondenten (bijna) altijd Nederlands gesproken. In $18 \%$ van de gevallen is dat Nederlands en een andere taal en $5 \%$ van de jongeren spreekt (bijna) altijd een andere taal. De verschillen tussen de opleidingsniveaus zijn groot. Onder de havo/ vwo respondenten spreekt 70\% (bijna) altijd Nederlands 


\section{Fact Sheet}

ROA-F-2018/18

thuis en voor mbo-respondenten geldt een percentage van $67 \%$. Op het vmbo ligt dit percentage met $55 \%$ duidelijk lager.

Over het algemeen is het opleidingsniveau van de ouders voor ongeveer $25 \%$ van de respondenten onbekend, en $34 \%$ meldt dat ten minste een van de ouders een ho-diploma heeft. Van de groep ongediplomeerde jongeren van de havo heeft zelfs $60 \%$ van de ouders een diploma in het hoger onderwijs terwijl voor ongediplomeerde jongeren van mbo niveau 1 dit percentage minder dan $20 \%$ is.

\section{Belangrijkste reden om te stoppen}

In deze paragraaf zal inzicht gegeven worden in de vraag waarom de jongeren voortijdig zijn gestopt. De redenen staan per categorie weergegeven in Figuur 1. De meer specifieke en onderliggende redenen per categorie staan vermeld in Bijlage Tabel B2.

Bijna de helft van de redenen die aangevoerd worden om te stoppen is school-gerelateerd (53\%). Ook gezondheidsproblemen (22\%) en de lonkende arbeidsmarkt (11\%) worden relatief vaak genoemd.

\section{FIGUUR 1.}

Belangrijkste reden voor uitval (\%)

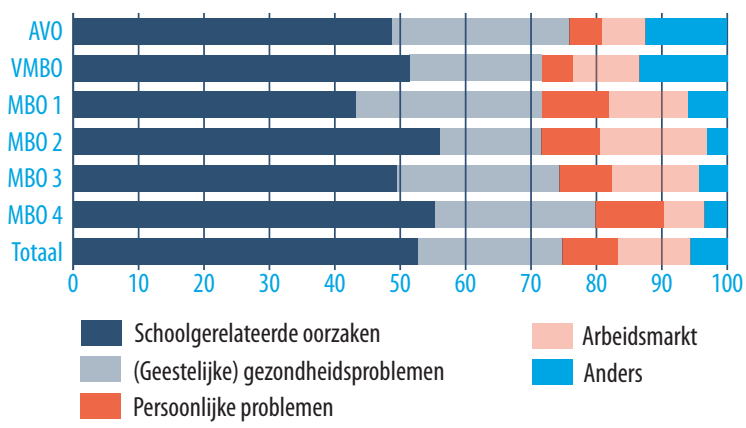

\section{Schoolgerelateerd}

Over het algemeen werden school-gerelateerde problemen het vaakst genoemd als reden voor het stoppen met de opleiding. Op mbo niveau 2 gaf $56 \%$ van de respondenten dit antwoord, terwijl deze reden op mbo niveau 1 nog steeds door $42 \%$ van de jongeren werd aangevoerd.
De belangrijkste individuele reden die wordt genoemd is de opleiding was inhoudelijk (toch) niet wat ik wilde (15\%). De reden de opleiding was slecht georganiseerd was bij $9 \%$ de belangrijkste reden. Problemen met taal en/of rekenen was bij minder dan $2 \%$ van de jongeren de belangrijkste reden om ongediplomeerd uit te vallen.

\section{(Geestelijke) gezondheidsklachten}

$22 \%$ van de respondenten geeft aan dat (geestelijke) gezondheidsklachten de belangrijkste reden was om voortijdig met de opleiding te stoppen. Op dit gebied wordt de reden psychische problemen het vaakst genoemd (14\%).

\section{Arbeidsmarkt}

Voor iets meer dan een op de tien jongeren is de arbeidsmarkt de belangrijkste reden voor voortijdige uitval, namelijk 11\%. In de meeste gevallen (8\%-punt) werden de jongeren naar de arbeidsmarkt toe getrokken: ze wilde liever gaan werken dan naar school. De overige jongeren (3\%-punt) gaven aan dat zij een inkomen nodig hadden en daarom gingen werken.

\section{Persoonlijke problemen}

$8 \%$ van de respondenten geeft aan dat persoonlijke problemen de belangrijkste factor was in het voortijdig verlaten van het onderwijs. Voor meer dan de helft van deze jongeren zijn relatie- of gezinsproblemen de onderliggende oorzaak.

\section{Anders}

Ondanks dat er getracht werd alle antwoorden die jongeren gaven te classificeren in bovengenoemde clusters, is voor $6 \%$ van de respondenten een nadere classificatie niet mogelijk, deze vallen onder de categorie anders. Vooral onder de groep jongeren die de middelbare school ongediplomeerd verlieten is dit een relatief vaak gegeven antwoord (13\%).

\section{Vroege signalen bij uitval}

Voor de overheid is het terugdringen van het aantal voortijdig schoolverlaters een belangrijk onderwerp. ${ }^{3}$ Een deel van de initiatieven om dit terug te dringen hebben te maken met het praten over en begeleiden van leerlingen die eventueel willen stoppen. Aan de jongeren is daarom gevraagd met wie zij gepraat 


\section{Uitval zonder diploma: Aanleiding, Kansen en Toekomstintenties}

hebben over de beslissing om te willen stoppen en wie probeert heeft hen te helpen met het voorkomen van de uitval.

\section{Praten over de beslissing}

In Tabel 1 is per opleidingsniveau weergegeven of de voortijdige uitvallers met iemand gesproken hebben over de keuze om met de opleiding te stoppen. Als dat zo was, dan is ook vermeld of dat met de ouders, met andere leden van het gezin, vrienden, of met leraren of mentoren is geweest. Over het algemeen geeft vier op de vijf jongeren aan een gesprek te hebben gehad over het voortijdig verlaten van de opleiding. Opvallend is dat van de jongeren die voortijdig een mbo niveau 1 of vmbo-opleiding hebben verlaten, respectievelijk $40 \%$ en $30 \%$ aangeven niet met iemand voorafgaand hierover gesproken te hebben.

Indien de jongeren wel met iemand gesproken hebben, of met meerdere hebben gesproken, is dat in ongeveer acht op de tien gevallen met de ouders, meer dan de helft van de respondenten praat met de school en ongeveer drie op de tien respondenten praat met andere gezinsleden of vrienden over de aanstaande voortijdig uitval.

Van de voortijdige uitvallers van havo/vwo die met iemand gesproken hebben over de keuze om met de opleiding te stoppen, wordt het meest met hun ouders gesproken (84\%). Voor jongeren die mbo niveau 1 voortijdig verlaten wordt relatief gezien het vaakst met iemand van de school gesproken (69\%).

\section{Aangeboden hulp}

Naast de signalering van eventuele voortijdige uitval naar aanleiding van een gesprek, kan een gesprek natuurlijk ook de eerste stap zijn om de jongeren te helpen om alsnog de opleiding af te ronden of een succesvolle overstap naar een andere opleiding te maken. Aan de jongeren is dan ook gevraagd of ze hulp ervaren hadden door het praten met iemand (zie Tabel 2).

Twee op de drie jongeren heeft hulp ervaren om het diploma alsnog te behalen of een andere opleiding te kiezen, variërend van zo'n $60 \%$ bij de jongeren die uiteindelijk met een mbo niveau 2 opleiding zijn gestopt tot $72 \%$ voor mbo niveau 3 jongeren. Ook als we kijken naar het aandeel dat hulp heeft ervaren per uiteindelijke reden voor de uitval, zien we dat (met uitzondering van de jongeren waarvoor de reden niet eenduidig vast was te stellen) minimaal zes op de tien jongeren aangeeft hulp te hebben ervaren. Kijken we tot slot met wie ze gesproken hebben, dan zien we dat $78 \%$ hulp heeft ervaren als zij met iemand van de school gesproken hebben, terwijl dit percentage voor ouders, andere gezinsleden en vrienden rond de 70\% ligt. 


\section{Fact Sheet}

ROA-F-2018/18

TABEL 1.

Met wie heb je gesproken over je keuze om met de opleiding te stoppen? (meerdere antwoorden mogelijk).

\begin{tabular}{|l|r|r|r|r|r|r|r|}
\hline & AV0 & VMBO & MB0 1 & MBO2 & MB0 3 & MB0 4 & Totaal \\
\hline Met iemand gesproken & $83 \%$ & $69 \%$ & $62 \%$ & $76 \%$ & $83 \%$ & $84 \%$ & $78 \%$ \\
\hline Ouders & & & & & & & \\
\hline Gezin/Vrienden & $84 \%$ & $81 \%$ & $71 \%$ & $72 \%$ & $82 \%$ & $77 \%$ & $77 \%$ \\
\hline Leraren/mentoren/begeleiders/zorgadviesteam op school & $42 \%$ & $16 \%$ & $21 \%$ & $20 \%$ & $32 \%$ & $34 \%$ & $29 \%$ \\
\hline Noot: AVO = HAVO/NWO & $50 \%$ & $51 \%$ & $69 \%$ & $59 \%$ & $60 \%$ & $61 \%$ & $58 \%$ \\
\hline
\end{tabular}

Noot: $A V O=H A V O / V W O$

TABEL 2.

Hulp ervaren (\%)

\begin{tabular}{|c|}
\hline \\
\hline Totaal \\
\hline Belangrijkste reden uitval \\
\hline School gerelateerde oorzaken \\
\hline (Geestelijke) gezondheidsproblemen \\
\hline Persoonlijke problemen \\
\hline Arbeidsmarkt \\
\hline Anders \\
\hline Opleidingsniveau \\
\hline AVO \\
\hline VMBO \\
\hline MBO 1 \\
\hline MBO 2 \\
\hline $\mathrm{MBO} 3$ \\
\hline MBO 4 \\
\hline Voortijdige uitvaller heeft gesproken met \\
\hline Ouders \\
\hline Gezin/vrienden \\
\hline Leraren, mentor \\
\hline
\end{tabular}




\section{Uitval zonder diploma: Aanleiding, Kansen en Toekomstintenties}

\section{Huidige bezigheden}

Wat Wat doen de jongeren zo'n anderhalf jaar na het uitvallen? In Tabel 3 staan de huidige bezigheden beschreven. Ongeveer drie op de tien jongeren is bezig aan een studie (28\%) en nog eens $17 \%$ is bezig met een werk/leertraject. Met andere woorden, bijna $45 \%$ is op de een of andere manier terug in het onderwijs. Voor de jongeren die niet terug in het onderwijs zijn gekomen is 38\% aan het werk, zo'n $6 \%$ ziet zich als werkloos en ongeveer $11 \%$ heeft een andere bezigheid.

De diversiteit tussen de opleidingsniveaus is groot. Uitvallers op de havo en het vwo zijn in meerderheid opnieuw met een opleiding begonnen (51\%) of zijn bezig aan een werk/leertraject (14\%). Van de jongeren afkomstig van het vmbo volgt $45 \%$ weer een opleiding en is $21 \%$ bezig met een werk/leertraject. Bij jongeren afkomstig van het mbo is werken prevalenter, waarbij het grootste deel van de jongeren afkomstig van niveau 2 en 3 werkt ( $57 \%$ en $46 \%$ respectievelijk).

De jongeren die de school voortijdig verlaten hebben vanwege de arbeidsmarkt werken het vaakst (71\%) en studeren het minst vaak (10\%) vergeleken met jongeren met andere redenen. Gezondheidsproblemen leiden het vaakst tot werkloosheid (9\%), wat kan indiceren dat gezondheidsklachten ook een probleem vormen op de arbeidsmarkt. Personen die zijn gestopt met hun opleiding vanwege persoonlijke problemen gaven het vaakst aan dat er een leer/werk traject wordt gevolgd (20\%). Jongeren die aangaven dat school-gerelateerde oorzaken de belangrijkste reden waren voor de uitval, volgen relatief gezien het vaakst opnieuw een opleiding (34\%).

\section{Toekomstplannen}

Buiten de huidige bezigheden van jongeren, is hen ook gevraagd wat hun plannen voor de toekomst zijn en voornamelijk of ze weer de intentie hebben om met een opleiding te beginnen. In hoeverre jongeren weer naar school gaan, laat ook zien in hoeverre jongeren bezig zijn om toch die startkwalificatie voor de arbeidsmarkt te behalen. Jongeren die op het moment van enquête weer in het onderwijs zitten, worden in deze paragraaf buiten beschouwing gelaten.

\section{Opleidingsplannen}

Zoals te zien is in Tabel 4, zijn zeven op de tien jongeren die nog niet opnieuw een opleiding volgen van plan om op een later tijdstip een opleiding te gaan volgen. Onder de jongeren van de havo en het vwo is dit zelfs $80 \%$ en onder de jongeren van het vmbo $90 \%$. Ook onder de jongeren die een mbo-opleiding zonder diploma hebben verlaten is minimaal $60 \%$ van plan om alsnog met een opleiding te starten.

\section{Afremmende factoren}

Aan de jongeren die zich nog niet ingeschreven hebben voor een nieuwe opleiding, is gevraagd welke factoren hen tegenhouden om met een nieuwe opleiding te beginnen (zie Tabel 5). De meeste genoemde reden buiten de mogelijkheid anders (25\%) was dat de kosten voor de opleiding te hoog zijn (23\%). Een op de vijf jongeren geeft aan dat ze geen zin meer hebben in het onderwijs en een even groot aandeel meldt dat persoonlijke omstandigheden hen hindert om momenteel onderwijs te gaan volgen. De cijfers kunnen, zeker onder jongeren van het avo, redelijke vertekend zijn aangezien een groot deel (40\%) van de jongeren redenen geven die niet geclassificeerd kunnen worden en daardoor in de categorie 'anders' terechtgekomen zijn.

\section{Stimulerende factoren}

Naast de afremmende factoren voor het beginnen van een nieuwe opleiding, is ook gevraagd naar stimulansen die de eventuele barrières zouden kunnen wegnemen om te beginnen met een nieuwe opleiding (zie Tabel 6). Ook hier dient opgemerkt te worden dat tussen de $25 \%$ ( $m$ bo niveau 1) en $45 \%$ (avo) van de respondenten een niet nader te specificeren reden heeft gegeven. Onder de bekende redenen zijn het wederom vooral financiële aspecten (financiële steun van de gemeente, studiefinanciering) die het vaakst genoemd worden. Naast geld is ook tijd een belemmerende factor voor de respondenten. 30\% van de respondenten geeft aan dat ze een opleiding zouden willen starten als ze deze naast hun huidige baan kunnen volgen.

\section{Spijt achteraf}

Tot slot staan we stil bij de vraag of de jongeren achteraf spijt hebben van het ongediplomeerd verlaten van de opleiding. In Tabel 7 zijn deze percentages uitgesplitst 


\section{Fact Sheet \\ ROA-F-2018/18}

TABEL 3.

Belangrijkste bezigheid op enquêtemoment (\%)

\begin{tabular}{|c|c|c|c|c|c|c|}
\hline & AVO & VMBO & MBO & Totaal & & \\
\hline werk & $16 \%$ & $13 \%$ & $44 \%$ & $38 \%$ & & \\
\hline studie & $51 \%$ & $45 \%$ & $22 \%$ & $28 \%$ & & \\
\hline combinatie werk-leren & $14 \%$ & $21 \%$ & $17 \%$ & $17 \%$ & & \\
\hline anders & $15 \%$ & $15 \%$ & $10 \%$ & $11 \%$ & & \\
\hline \multirow[t]{3}{*}{ werkloos } & $5 \%$ & $7 \%$ & $7 \%$ & $6 \%$ & & \\
\hline & $100 \%$ & $100 \%$ & $100 \%$ & $100 \%$ & & \\
\hline & $\begin{array}{r}\text { Schoolgerelateerde } \\
\text { oorzaken }\end{array}$ & $\begin{array}{r}\text { (geestelijke) } \\
\text { Gezondheidsproblemen }\end{array}$ & $\begin{array}{l}\text { Persoonlijke } \\
\text { problemen }\end{array}$ & Arbeidsmarkt & Anders & Totaal \\
\hline werk & $36 \%$ & $31 \%$ & $37 \%$ & $71 \%$ & $29 \%$ & $38 \%$ \\
\hline studie & $34 \%$ & $18 \%$ & $21 \%$ & $10 \%$ & $45 \%$ & $27 \%$ \\
\hline combinatie werk-leren & $19 \%$ & $14 \%$ & $20 \%$ & $13 \%$ & $8 \%$ & $16 \%$ \\
\hline anders & $6 \%$ & $29 \%$ & $15 \%$ & $3 \%$ & $10 \%$ & $12 \%$ \\
\hline \multirow[t]{2}{*}{ werkloos } & $6 \%$ & $9 \%$ & $8 \%$ & $3 \%$ & $9 \%$ & $7 \%$ \\
\hline & $100 \%$ & $100 \%$ & $100 \%$ & $100 \%$ & $100 \%$ & $100 \%$ \\
\hline
\end{tabular}

TABEL 4.

Ben je van plan om op een later tijdstip nog een opleiding te gaan opleidingen? (\%)

\begin{tabular}{|l|r|r|r|r|r|r|r|}
\hline & AVO & VMBO & MBO 1 & MBO2 & MBO3 & MBO 4 & Totaal \\
\hline ja en ingeschreven & $15 \%$ & $12 \%$ & $3 \%$ & $4 \%$ & $10 \%$ & $10 \%$ & $8 \%$ \\
\hline ja maar onduidelijk & $66 \%$ & $80 \%$ & $57 \%$ & $58 \%$ & $61 \%$ & $72 \%$ & $63 \%$ \\
\hline welke wanneer & & & & & & & \\
\hline nee & $19 \%$ & $8 \%$ & $40 \%$ & $38 \%$ & $29 \%$ & $17 \%$ & $29 \%$ \\
\hline
\end{tabular}




\section{Uitval zonder diploma: Aanleiding, Kansen en Toekomstintenties}

naar opleidingsniveau en in Tabel 8 naar de reden van de uitval.

\section{Spijt naar opleidingsniveau}

lets meer dan de helft van de jongeren heeft geen spijt van het ongediplomeerd verlaten van de opleiding. Onder de jongeren afkomstig van het vmbo en het avo is dit zelfs iets meer dan 60\%. Dit is in schril contrast tot de jongeren van mbo niveau 1 opleidingen waar meer dan 60\% wel spijt heeft. De groep die spijt heeft, kan verder onderverdeeld worden in diegenen die spijt hebben maar destijds geen andere keuze zagen (35\%) en degenen die aangeven spijt te hebben en achteraf ook vinden dat ze een foute keuze gemaakt hebben $(11 \%)$. De laatste groep jongeren is relatief hoog voor mbo niveau 1 respondenten ( $25 \%$ zou dat achteraf niet meer doen), terwijl de groep jongeren die aangeeft dat ze spijt hebben maar destijds niet anders konden relatief groot is onder mbo niveau 2 respondenten (40\%).

\section{Spijt naar reden van de uitval}

Jongeren die vanwege school-gerelateerde of arbeidsmarkt gerelateerde redenen de opleiding voortijdig verlieten, hebben relatief het minste spijt dat ze de opleiding verlieten. Niet verrassend zien we dat jongeren die wegens (geestelijke) gezondheidsproblemen dan wel persoonlijke problemen de opleiding verlieten relatief vaak aangeven spijt te hebben maar destijds niet anders konden.

\section{Conclusies}

In deze factsheet zijn cijfers gepresenteerd over jongeren onder de 23 jaar die een opleiding in het voortgezet onderwijs dan wel het middelbaar beroepsonderwijs zonder diploma hebben verlaten en niet in bezit zijn van een arbeidsmarkt kwalificerend diploma. De belangrijkste bevindingen zijn:

- Een op de twee jongeren geeft aan gestopt te zijn met de opleiding wegens school gerelateerde redenen (53\%). Ook gezondheidsproblemen (22\%) en de lonkende arbeidsmarkt (11\%) worden relatief vaak genoemd. Onderaan de lijst staat de categorie persoonlijke problemen (8\%).

- Bij ongeveer acht op de tien voortijdig uitvallers heeft er een gesprek plaatsgevonden over het voortijdig uitvallen van de opleiding. Indien de respondent met iemand gesproken heeft, is dat in driekwart van de gevallen met de ouders, in meer dan de helft van de gevallen met iemand van de school en ongeveer drie op de tien jongeren praat met andere gezinsleden of vrienden over de aanstaande voortijdig uitval. Twee op de drie jongeren geeft aan dat ze hulp hebben ervaren door te praten over het voortijdige uitvallen om alsnog het diploma te behalen dan wel over te stappen naar een andere opleiding. Uiteindelijk was deze hulp niet voldoende om voortijdig uitvallen tegen te gaan.

- Zo'n vier op de tien jongeren is anderhalf jaar later aan het werk, bijna $30 \%$ is weer bezig met een voltijd studie nog eens $17 \%$ is bezig met een werk/leertraject.

- Van de jongeren die (nog) niet opnieuw een opleiding volgen, is $71 \%$ van plan om op een later tijdstip alsnog een opleiding te gaan volgen. De meest genoemde afremmende factor om opnieuw aan een opleiding te beginnen, zijn de te hoge kosten die aan een opleiding verbonden zijn.

- lets meer dan de helft van de jongeren heeft geen spijt dat ze destijds de opleiding zonder diploma hebben verlaten. 


\section{Fact Sheet \\ ROA-F-2018/18}

TABEL 5.

Wat houd je tegen om met een nieuwe opleiding te beginnen? (meerdere antwoorden mogelijk) (\%)

\begin{tabular}{|c|c|c|c|c|c|c|c|}
\hline & AVO & VMBO & MB0 1 & $\mathrm{MBO} 2$ & MBO3 & $\mathrm{MBO} 4$ & Totaal \\
\hline Ik weet niet welke opleidingen er zijn & $17 \%$ & $13 \%$ & $22 \%$ & $13 \%$ & $13 \%$ & $13 \%$ & $14 \%$ \\
\hline De opleiding die ik wil doen heeft geen plek meer vrij & $1 \%$ & $1 \%$ & $6 \%$ & $2 \%$ & $1 \%$ & $4 \%$ & $3 \%$ \\
\hline De opleiding die ik wil doen is te ver weg & $1 \%$ & $4 \%$ & $4 \%$ & $3 \%$ & $2 \%$ & $5 \%$ & $3 \%$ \\
\hline Ik voldoe niet aan de minimale eisen om met de opleiding te beginnen & $15 \%$ & $16 \%$ & $20 \%$ & $13 \%$ & $8 \%$ & $11 \%$ & $13 \%$ \\
\hline Ik moet nog wachten omdat dit slechts op een beperkt aantal momenten kan & $9 \%$ & $7 \%$ & $0 \%$ & $4 \%$ & $5 \%$ & $11 \%$ & $6 \%$ \\
\hline De kosten zijn te hoog & $16 \%$ & $9 \%$ & $16 \%$ & $27 \%$ & $31 \%$ & $22 \%$ & $23 \%$ \\
\hline Ik kan via mijn werk verder leren & $5 \%$ & $11 \%$ & $10 \%$ & $20 \%$ & $21 \%$ & $16 \%$ & $16 \%$ \\
\hline Ik heb geen verdere studie nodig & $7 \%$ & $3 \%$ & $8 \%$ & $7 \%$ & $7 \%$ & $7 \%$ & $7 \%$ \\
\hline Ik wil me door middel van cursussen verder ontwikkelen & $14 \%$ & $8 \%$ & $4 \%$ & $20 \%$ & $22 \%$ & $18 \%$ & $17 \%$ \\
\hline Het is niet mogelijk vanwege persoonlijke omstandigheden & $27 \%$ & $18 \%$ & $25 \%$ & $14 \%$ & $12 \%$ & $27 \%$ & $19 \%$ \\
\hline Ik heb geen zin meer in het onderwijs & $17 \%$ & $10 \%$ & $21 \%$ & $26 \%$ & $26 \%$ & $22 \%$ & $23 \%$ \\
\hline Anders, namelijk & $42 \%$ & $35 \%$ & $24 \%$ & $20 \%$ & $22 \%$ & $28 \%$ & $25 \%$ \\
\hline
\end{tabular}

TABEL 6.

Wat zou je kunnen stimuleren om met een nieuwe opleiding te beginnen? (meerdere antwoorden mogelijk)(\%)

\begin{tabular}{|c|c|c|c|c|c|c|c|}
\hline & AVO & VMBO & MBO 1 & $\mathrm{MBO} 2$ & MBO 3 & MBO 4 & Totaal \\
\hline Het krijgen van studiefinanciering & $37 \%$ & $45 \%$ & $31 \%$ & $29 \%$ & $35 \%$ & $39 \%$ & $34 \%$ \\
\hline Financiële steun van de gemeente & $18 \%$ & $18 \%$ & $18 \%$ & $29 \%$ & $35 \%$ & $36 \%$ & $29 \%$ \\
\hline Als ik de opleiding naast mijn huidige baan zou kunnen volgen & $11 \%$ & $16 \%$ & $23 \%$ & $33 \%$ & $38 \%$ & $36 \%$ & $31 \%$ \\
\hline Als ik op korte termijn zou kunnen beginnen & $8 \%$ & $11 \%$ & $13 \%$ & $13 \%$ & $9 \%$ & $9 \%$ & $11 \%$ \\
\hline Hulp bij de studiekeuze zodat ik weet wat voor een opleiding ik wil gaan doen & $24 \%$ & $28 \%$ & $45 \%$ & $21 \%$ & $30 \%$ & $23 \%$ & $26 \%$ \\
\hline Anders, namelijk & $45 \%$ & $27 \%$ & $25 \%$ & $27 \%$ & $27 \%$ & $26 \%$ & $28 \%$ \\
\hline
\end{tabular}

TABEL 7.

Spijt achteraf, naar opleidingsniveau (\%)

\begin{tabular}{|c|c|c|c|c|c|c|c|}
\hline & AVO & VMBO & MBO 1 & $\mathrm{MBO} 2$ & $\mathrm{MBO} 3$ & $\mathrm{MBO} 4$ & Totaal \\
\hline Nee & $64 \%$ & $62 \%$ & $37 \%$ & $46 \%$ & $60 \%$ & $58 \%$ & $54 \%$ \\
\hline Ja, dat zou ik nu niet meer doen & $7 \%$ & $12 \%$ & $25 \%$ & $14 \%$ & $11 \%$ & $7 \%$ & $11 \%$ \\
\hline \multirow[t]{2}{*}{ Ja, maar ik kon destijds niet anders } & $29 \%$ & $26 \%$ & $38 \%$ & $40 \%$ & $29 \%$ & $35 \%$ & $35 \%$ \\
\hline & $100 \%$ & $100 \%$ & $100 \%$ & $100 \%$ & $100 \%$ & $100 \%$ & $100, \%$ \\
\hline
\end{tabular}

TABEL 8.

Spijt achteraf, naar belangrijkste reden voor de voortijdige uitval (\%)

\begin{tabular}{|l|r|r|r|r|r|r|} 
& $\begin{array}{r}\text { school gerelateerde } \\
\text { oorzaken }\end{array}$ & $\begin{array}{r}\text { (geestelijke) } \\
\text { gezondheidsproblemen }\end{array}$ & $\begin{array}{r}\text { persoonlijke } \\
\text { problemen }\end{array}$ & arbeidsmarkt \\
\hline Nee & $61 \%$ & $41 \%$ & $29 \%$ & $55 \%$ & $71 \%$ \\
\hline Ja, dat zou ik nu niet meer doen & $12 \%$ & $7 \%$ & $15 \%$ & $20 \%$ & $54 \%$ \\
\hline Ja, maar ik kon destijds niet anders & $27 \%$ & $52 \%$ & $56 \%$ & $26 \%$ & $12 \%$ \\
\hline
\end{tabular}




\section{Uitval zonder diploma: Aanleiding, Kansen en Toekomstintenties}

\section{Bijlagen}

TABEL B1.

Achtergrondkenmerken respondenten (\%)

\begin{tabular}{|c|c|c|c|c|c|c|c|}
\hline & AVO & VMBO & MBO 1 & $\mathrm{MBO} 2$ & MBO3 & MBO 4 & Totaal \\
\hline Totaal & $13 \%$ & $9 \%$ & $7 \%$ & $31 \%$ & $13 \%$ & $28 \%$ & 100 \\
\hline Algemeen & $100 \%$ & $81 \%$ & $8 \%$ & $0 \%$ & $0 \%$ & $0 \%$ & $20 \%$ \\
\hline Landbouw & & $4 \%$ & $4 \%$ & $5 \%$ & $6 \%$ & $3 \%$ & $4 \%$ \\
\hline Techniek & & $3 \%$ & $6 \%$ & $36 \%$ & $15 \%$ & $29 \%$ & $22 \%$ \\
\hline Economie & & $8 \%$ & $78 \%$ & $41 \%$ & $43 \%$ & $35 \%$ & $34 \%$ \\
\hline Gezondheidszorg & & $5 \%$ & $4 \%$ & $18 \%$ & $19 \%$ & $22 \%$ & $15 \%$ \\
\hline Gedrag \& maatschappij & & $0 \%$ & $0 \%$ & $0 \%$ & $17 \%$ & $11 \%$ & $5 \%$ \\
\hline Theoretisch & & $61 \%$ & & & & & \\
\hline Gemengd & & $2 \%$ & & & & & \\
\hline Kaderberoepsgericht & & $15 \%$ & & & & & \\
\hline Basisberoepsgericht & & $22 \%$ & & & & & \\
\hline Leeftijd (gemiddelde) & 19,6 & 18,3 & 19,9 & 20,4 & 20,3 & 20,3 & 20,0 \\
\hline Man & $60 \%$ & $69 \%$ & $58 \%$ & $66 \%$ & $61 \%$ & $62 \%$ & $63 \%$ \\
\hline Vrouw & $40 \%$ & $31 \%$ & $42 \%$ & $34 \%$ & $39 \%$ & $38 \%$ & $37 \%$ \\
\hline Westerse allochtoon & $10 \%$ & $11 \%$ & $3 \%$ & $8 \%$ & $6 \%$ & $9 \%$ & $8 \%$ \\
\hline Niet-westerse allochtoon & $30 \%$ & $47 \%$ & $33 \%$ & $28 \%$ & $21 \%$ & $28 \%$ & $29 \%$ \\
\hline Autochtoon & $60 \%$ & $42 \%$ & $64 \%$ & $64 \%$ & $73 \%$ & $63 \%$ & $62 \%$ \\
\hline Tweeoudergezin & $60 \%$ & $63 \%$ & $42 \%$ & $62 \%$ & $55 \%$ & $63 \%$ & $60 \%$ \\
\hline Eenoudergezin & $19 \%$ & $22 \%$ & $32 \%$ & $23 \%$ & $28 \%$ & $22 \%$ & $23 \%$ \\
\hline Zelfstandig & $17 \%$ & $15 \%$ & $24 \%$ & $12 \%$ & $14 \%$ & $12 \%$ & $14 \%$ \\
\hline Anders & $4 \%$ & $0 \%$ & $2 \%$ & $3 \%$ & $4 \%$ & $3 \%$ & $3 \%$ \\
\hline (Bijna) altijd Nederlands & $70 \%$ & $55 \%$ & $50 \%$ & $64 \%$ & $76 \%$ & $71 \%$ & $66 \%$ \\
\hline Nederlands en een andere taal & $21 \%$ & $15 \%$ & $24 \%$ & $19 \%$ & $12 \%$ & $19 \%$ & $18 \%$ \\
\hline (Bijna) altijd een andere taal & $4 \%$ & $9 \%$ & $7 \%$ & $6 \%$ & $2 \%$ & $3 \%$ & $5 \%$ \\
\hline Niet van toepassing & $6 \%$ & $21 \%$ & $19 \%$ & $11 \%$ & $10 \%$ & $7 \%$ & $11 \%$ \\
\hline Basisonderwijs & $3 \%$ & $7 \%$ & $9 \%$ & $1 \%$ & $2 \%$ & $2 \%$ & $3 \%$ \\
\hline Lager beroepsonderwijs (lbo/vbo/vmbo/mavo) & $3 \%$ & $4 \%$ & $9 \%$ & $15 \%$ & $12 \%$ & $10 \%$ & $10 \%$ \\
\hline Voortgezet onderwijs (havo/vwo) & $7 \%$ & $6 \%$ & $8 \%$ & $7 \%$ & $7 \%$ & $4 \%$ & $6 \%$ \\
\hline Middelbaar beroepsonderwijs & $15 \%$ & $14 \%$ & $10 \%$ & $28 \%$ & $23 \%$ & $25 \%$ & $22 \%$ \\
\hline Hoger onderwijs & $60 \%$ & $37 \%$ & $19 \%$ & $20 \%$ & $34 \%$ & $42 \%$ & $34 \%$ \\
\hline Onbekend & $12 \%$ & $33 \%$ & $45 \%$ & $29 \%$ & $21 \%$ & $17 \%$ & $24 \%$ \\
\hline
\end{tabular}




\section{Fact Sheet \\ ROA-F-2018/18}

Tabel B2

Belangrijkste reden voor voortijdige uitval (\%)

\begin{tabular}{|c|c|c|c|c|c|c|c|c|}
\hline & & AV0 & VMBO & MBO 1 & $\mathrm{MBO} 2$ & MBO3 & MBO 4 & Totaal \\
\hline \multirow[t]{10}{*}{ Schoolgerelateerde oorzaken } & De opleiding was te moeilijk en/of gezakt voor het eindexamen & $24,4 \%$ & $7,5 \%$ & $4,5 \%$ & $4,7 \%$ & $1,3 \%$ & $4,0 \%$ & $6,7 \%$ \\
\hline & Problemen op de leerwerkplek/stage (bijv. ontslag) & $0,4 \%$ & $3,9 \%$ & $4,3 \%$ & $5,4 \%$ & $6,1 \%$ & $2,0 \%$ & $3,7 \%$ \\
\hline & Geen stageplek kunnen vinden & $0 \%$ & $2,2 \%$ & $4,8 \%$ & $2,6 \%$ & $4,0 \%$ & $1,0 \%$ & $2,1 \%$ \\
\hline & Problemen met de leraren/schoolleiding & $4,6 \%$ & $6,5 \%$ & $3,5 \%$ & $3,9 \%$ & $3,3 \%$ & $6,4 \%$ & $4,8 \%$ \\
\hline & Problemen met andere leerlingen & $0 \%$ & $3,4 \%$ & $1,1 \%$ & $2,4 \%$ & $0 \%$ & $1,3 \%$ & $1,5 \%$ \\
\hline & Ik wilde van opleiding wisselen & $7,7 \%$ & $10,5 \%$ & $2,6 \%$ & $6,5 \%$ & $3,7 \%$ & $6,7 \%$ & $6,4 \%$ \\
\hline & De opleiding was inhoudelijk (toch) niet wat ik wilde & $5,0 \%$ & $2,3 \%$ & $2,8 \%$ & $14,4 \%$ & $18,6 \%$ & $23,1 \%$ & $14,5 \%$ \\
\hline & Ik vond het niveau van de opleiding te laag & $1,3 \%$ & $11,0 \%$ & $6,2 \%$ & $2,7 \%$ & $0,7 \%$ & $2,3 \%$ & $3,1 \%$ \\
\hline & Vanwege problemen met taal en/of rekenen & $0,3 \%$ & $1,6 \%$ & $10,1 \%$ & $0,9 \%$ & $1,4 \%$ & $0,1 \%$ & $1,3 \%$ \\
\hline & De opleiding was slecht georganiseerd & $4,9 \%$ & $2,7 \%$ & $2,4 \%$ & $12,5 \%$ & $10,2 \%$ & $8,3 \%$ & $8,6 \%$ \\
\hline Subtotaal & & $48,6 \%$ & $51,6 \%$ & $42,3 \%$ & $56 \%$ & $49,3 \%$ & $55,2 \%$ & $52,7 \%$ \\
\hline \multirow[t]{2}{*}{ (Geestelijke) gezondheidsklachten } & Problemen met gezondheid, bijv. ziekte of verslavingsproblemen & $5,7 \%$ & $9,3 \%$ & $10,0 \%$ & $7,3 \%$ & $11,5 \%$ & $8,3 \%$ & $8,3 \%$ \\
\hline & Psychische problemen & $21,6 \%$ & $11,0 \%$ & $18,9 \%$ & $8,2 \%$ & $13,5 \%$ & $16,4 \%$ & $13,8 \%$ \\
\hline \multirow[t]{2}{*}{ Subtotaal } & & $27,3 \%$ & $20,3 \%$ & $28,9 \%$ & $15,5 \%$ & $25,0 \%$ & $24,7 \%$ & $22,1 \%$ \\
\hline & & & & & & & & \\
\hline \multirow[t]{2}{*}{ Persoonlijke problemen } & Relatieproblemen/gezinsproblemen (bijv. scheiding van ouders & $4,2 \%$ & $2,9 \%$ & $2,3 \%$ & $6,4 \%$ & $5,9 \%$ & $6,7 \%$ & $5,6 \%$ \\
\hline & $\begin{array}{l}\text { School in combinatie met zorg voor kinderen en/of familie was te } \\
\text { zwaar }\end{array}$ & $0,7 \%$ & $1,7 \%$ & $7,9 \%$ & $2,5 \%$ & $2,1 \%$ & $3,7 \%$ & $2,8 \%$ \\
\hline Subtotaal & & $4,9 \%$ & $4,6 \%$ & $10,2 \%$ & $8,9 \%$ & $8,0 \%$ & $10,4 \%$ & $8,4 \%$ \\
\hline \multirow[t]{2}{*}{ Arbeidsmarkt } & Ik wilde liever gaan werken & $2,9 \%$ & $6,8 \%$ & $8,4 \%$ & $11,5 \%$ & $9,3 \%$ & $4,7 \%$ & $7,6 \%$ \\
\hline & Ik had een inkomen nodig en ben daarom gaan werken & $3,8 \%$ & $3,4 \%$ & $3,7 \%$ & $4,8 \%$ & $4,0 \%$ & $1,5 \%$ & $3,4 \%$ \\
\hline Subtotaal & & $6,7 \%$ & $10,2 \%$ & $12,1 \%$ & $16,3 \%$ & $13,3 \%$ & $6,2 \%$ & $11,0 \%$ \\
\hline \multirow[t]{2}{*}{ Anders } & Ik ging verhuizen & $2,2 \%$ & $7,5 \%$ & $2,7 \%$ & $1,7 \%$ & $1,5 \%$ & $0,5 \%$ & $2,0 \%$ \\
\hline & Anders & $10,3 \%$ & $6,0 \%$ & $3,8 \%$ & $1,4 \%$ & $2,8 \%$ & $3,0 \%$ & $3,7 \%$ \\
\hline Subtotaal & & $12,5 \%$ & $13,5 \%$ & $6,5 \%$ & $3,1 \%$ & $4,3 \%$ & $3,5 \%$ & $5,7 \%$ \\
\hline
\end{tabular}




\section{Colofon}

(๑) Researchcentrum voor Onderwijs en Arbeidsmarkt Niets uit deze uitgave mag op enige manier worden verveelvoudigd zonder voorafgaande schriftelijke toestemming van de directeur van het ROA.

Deze factsheet maakt onderdeel uit van het NRO project Project Onderwijs-Arbeidsmarkt' (dossiernummer 405-17-900).

\section{Researchcentrum voor Onderwijs en Arbeidsmarkt}

Maastricht University

School of Business and Economics

secretary-roa-sbe@maastrichtuniversity.nl

www.roa.nl

\section{Vormgeving}

ROA secretariaat, Maastricht

oktober 2018 